The Geneva Papers on Risk and Insurance, 8 (No 28, July 1983), 213-226

\title{
Science and Practice of Insurance *
}

\author{
by Reimer Schmidt **
}

\section{Preliminary remarks}

No matter how moving the subject is, the following sequence of ideas is necessarily "dry" and "inconvenient". But maybe these ideas will nevertheless contribute to a further improvement of the relationship between science and practice, all the more so since the author has to deal with this phenomenon by opposing himself, as it were.

The sequence of ideas comes after some consideration on the concept of science, it deals with the individual fields of insurance science, then takes a more detailed look at the influence these fields of science have on application (practice) and finally, and necessarily in quite a brief manner, it deals with the significance the practice of insurance has on science.

A lecture like this can neither be expected to give a report on the development of the concept of science and the modern theory of science ${ }^{1}$ nor to give a definition of its own. Science is linked with an inspirational thinking process involving human creativeness. If, however, we considered everything taught at a university chair to be science in a formal sense ${ }^{2}$ we would surely see a large discrepancy between the formal and the substantial approach. In the final analysis science is to enhance knowledge and the progress of mankind. The intellectual process can only meet with moral approval if it is borne by the scientists's sense of responsibility and therefore deserves the confidence of the general public.

In this context we should not start out from a pre-eminence of science over practice. Neither does the author integrate science into a scientific system of supremacy (in a sociological sense) nor does he accept such a system. ${ }^{3}$

* Lecture held on Nov. 11, 1980 in Munich at the Verein zur Förderung der Versicherungswissenschaft in München e.V. ZVersWiss 1980, pp. $515 \mathrm{ff}$.

** President of the Aufsichtsrat, Aachener und Münchener Beteiligungs-Aktiengesellschaft and Aachener und Münchener Versicherung Aktiengesellschaft, Aachen.

1 Cf. Neumann, in Kaufmann-Hassemer, Einführung in Rechtsphilosophie und Rechtstheorie der Gegenwart, 1977, pp. 174 ff., p. 175 ; Janich/Kambartel/Mittelstrass, Wissenschaftstheorie als Wissenschaftskritik, 1974, pp. 22 ff.

2 Winkler, Rechtstheorie und Rechtsinformatik, 1975, p. 3.

3 Cf. e.g. criticism by Schelsky, Die Wirtschaftswissenschaft und die Erfahrung des Wirtschaftens, Christmas gift 1980 by Betriebswirtschaftlicher Verlag Dr. Th. Gabler, Wiesbaden. 
The author regards insurance practice as a kind of " commercial art" the decisive element of which purely and simply is the commercial, organizational and general mathematical skill pertaining to this trade and where the knowledge based on experience is passed on from generation to generation. The vast majority of the decisions we are going to look at are not taken by applying the results of science - not even with the knowledge of these results - ; they are frequently not based on planning, often not even on the principles of logic, but they are pragmatic decisions taken out of the situation existing at the moment.

Although the subject of this paper contains the word "practice" it is evident that the subject necessarily is a rather theoretical one at first. In fact, the couple of opposing concepts in this much discussed subject should rather read "theory and practice" than "science and practice", in the abstract and concrete sense. But among the questions to be studied the concept of theory is also quite "colourless". Science, in fact, means something other than mere abstraction. The latter is only one of the logical instruments of science. Science is a superordinated matter.

\section{Classification into the three fields of science, technique and application}

Whoever has to deal intellectually with technical science like the author does, will prefer a three-step classification into science, technique 4 and application to the pure "primitive" polarity between science and practice also in the partial fields of social sciences and humanities. For all three steps we have to ask for the objective, the methods and the benefit. Such three-step classification is first taken as a basis in the form of a working hypothesis and will then proceed by means of the following sequences of ideas. Thus the subject is to read "Science, technique and application as related to insurance".

Science is only imaginable at a certain minimum level. 5 There are different levels : those of philosophers, theorectical mathematicians and physicists are traditionally considered to be particularly high and, in contrast to this, whether rightly or wrongly, a lower rank is attributed to insurance sciences. By making a distinction between science and technique the lower levels are eliminated from the science area. They concern the "construction rules" developed for renewing, improving and facilitating application according to different thinking methods and with different objectives. Here the accent is thus put in a different way than, for instance, by Popper who simply looks at technique and applied science as the testing of scientific principles ${ }^{6}$. It is

4 So this does not mean technology in the sense of applied natural science which, of course, is also used in insurance if we recall, for instance, the numerous papers by Danner, among others ZVersWiss 1972, pp. $17 \mathrm{ff}$., pp. $285 \mathrm{ff}$.

Translator's note: The German word "Technik" has the meaning of "technology" and "technique" so that above note was made in order to avoid any misunderstandings.

5 Maier-Leibnitz, Zwischen Wissenschaft und Politik, 1979, pp. 166 f.

6 Popper, Logik der Forschung, 3rd edition 1969, pp. 71, 74-75; idem., Objektive Erkenntnis, 2nd edition 1974, e.g. p. 377 ; more in the sense above Albert, Traktat über rationale Praxis, 1978, with respect to "technology", e.g. p. 75. 
justified then to use the term "insurance technique" beyond the traditional specialized field of underwriting in a narrower sense, such as e.g. the technique of organization, of data processing, of capital investments and capital administration. In this sense there is also a legal technique. The boundaries between science and technique as well as between technique and application are fluent. In the field of applied natural science we therefore speak of technique as becoming more and more scientific ?.

Although the door of access into the thinking processes of the higher levels of scientific thinking is closed to the general public and to the organs of public opinion, moral standards applied to research are high, also because the scientific findings are quite frequently taken as a basis for political decisions or used for their formal justification. The representatives of sociology in a larger sense are particularly exposed to the temptation of scientifically justifying results desired by social groups ${ }^{8}$.

\section{International character and group research}

Science on a higher level, if it serves human progress in general, has an international character. On an international level we find parallels when judging basic facts, optimizing methods, making efforts concerning scientific languages, and collecting and exchanging results which, in turn, become the basic facts for new research or sequences of thought. Despite a certain international character of practice - if we think in particular of the international cooperation of actuaries but also of the A.I.D.A. (Association Internationale de Droit des Assurances) and the so-called Geneva Association ${ }^{9}$ - insurance sciences find themselves on international ground to a limited extent only : in those fields of the probability calculus pertaining to insurance, in economic approaches and examination methods, in comparative law, to name three examples. Due to the fact that we use our language for publication, events are only taken note of internationally if the publications are at least accompanied by summaries in a foreign language ${ }^{10}$.

In the research field of natural science the use of research teams ${ }^{11}$ with a division of labour and certain rules of cooperation fixed beforehand (team work) plays a major role, because in this manner there are greater chances of successfully handling the empiric material. Surely this also applies to empiric social sciences, as well as to fields of jurisprudence, such as comparative law. In insurance sciences, however, we find for the most part individual scientists who have a few assistants, and are not involved in group research, if we leave the work of the Max-Planck-Institutes aside.

7 E.g. Trendelenburg, in Naturwissenschaft, Technik und Wissenschaft im 19. Jahrhundert, vol. 2,1976 , pp. $542 \mathrm{ff}$.

8 In this respect e.g. Schelsky, ibid., pp. $22 \mathrm{ff}$.

9 Association Internationale pour l'Etude de l'Economie de l'Assurance, Geneva.

$10 \mathrm{Cf}$. the summaries ZVersWiss has been publishing for some years.

11 Maier-Leibnitz, ibid., pp. $103 \mathrm{ff}$. 


\section{The language problem}

In the past few decades the significance of language for science ${ }^{12}$ has become particularly evident. Only by means of a "special language" is it possible to specify and convey scientific thinking processes. An index is added to the world of colloquial language, as it were, unless artificial terms or the abstraction of mathematical terms can be used. At the same time the countless number of special scientific languages ${ }^{13}$, out of necessity, are intellectual hierarchies - in part manneristic ones - of the specialized discipline, even of individual scientists, and above all, in philosophy. The generally acknowledged terms of technical languages are maintained in technique and in part even in application. This is also true of the insurance industry, as is shown by a look at the "Versicherungsalphabet" (Insurance Alphabet) 14 which focuses on the requirements of technique and application. Of course, it often happens that the same facts and functions have different names in the technical languages of the individual sciences and it is not rare that different facts have the same names or similar ones. Therefore, as an antithesis to this development the requirement of simplicity and clearness is appearing with might 15 .

\section{Insurance sclence as a collective science}

It is a known fact that science approaches the subject of insurance from the rather differing initial positions of the individual fields of insurance, of mathematics, of economic science, of jurisprudence and of medecine ${ }^{16}$. The view expressed for a time that "insurance science" was a uniform science ${ }^{17}$ could not be maintained. The "partial" fields of science which, in fact, are kept together, as it were, by the subject matter of studies, thus have to be attributed in part to natural sciences and in part to social sciences. With respect to natural and social sciences/humanities it is even possible to speak of two different cultures, as Charly Percy Snow did for natural scientists and writers and as Heinz Maier-Leibnitz put it in more general terms in the sense presented ${ }^{18}$.

It is difficult to find superordinated aspects for judgement. But it may be permissible to state that the nature of the matter of insurance, apart from its classification

$12 \mathrm{Cf}$. in this context Hattemer, ZVersWiss 1979, pp. 565 ff. with further references ; Maier-Leibnitz, ibid., pp. 149 ff.; Report of ZfV (1980, p. 680) on a lecture by Els Oksaar.

13 Cf. Möller, Zur Terminologie des Versicherungswesens, in Lobscheid, Gegenwartsfragen der Versicherung, 1962, p. $11 \mathrm{ff}$.

14 Reimer Schmidt, 5th edition 1976.

15 Reimer Schmidt, ZVersWiss 1973, pp. 529 ff.

16 In this context we also have to mention other " risk related" natural sciences, such as physics, chemistry, engineering, meteorology, because of the risk and claims phenomena arising here.

17 Rohrbeck, Versicherungswissenschaft und Versicherungswirtschaft, in Grund- und Zeitfragen der Versicherungswirtschaft und Versicherungswissenschaft, edited by Rohrbeck, 1941, pp. 35 ff., in particular pp. 42 ff. ; Eichler, VersArch 1957, pp. 220 ff.

18 Maier-Leibnitz, ibid., pp. 165 ff. 
within the national economy ${ }^{19}$, which is not easy, shows essential mathematical and important microeconomic features and that the benefits and detriments of application are predominantly judged from sociological aspects in a larger sense. Accordingly the analyses presented here remain incomplete and in need of verification, especially with respect to the mathematical and the medical components.

What both fields, natural as well as social sciences, have in common is that they use the instrument of logic and in social sciences as well these instruments do not, to any small extent, have the form of mathematical structures of thinking. In addition there is a certain aproximation between the two fields by the more quantifying thinking method of social science, especially in economics. But for the most part social sciences generally lack the dominant corrective of a possible verification by the "practical" experiment. They have less access to pragmatical possibilities of judgement, which, however, do exist in the empiric field. In social sciences, however, valuation plays a special part which I will refer to later. Although aspiring for "truth" science in its methods and objectives is not free of the spirit of the times either - it is also subject to "fashions" 20.

\section{Starting positions of science, technlques and appllcatlons}

The fields of application of scientific thinking in the insurance sector are in the first place characterized by the aspect of providing cover for a reduction of assets or an increase of liabilities of the insured and secondly by the special methods (typical of insurance) of raising the means for covering demand. Consequently the headlight of the scientific approach continues to be directed at the formation and management of collectives, at preventing, reducing, registering and compensating losses as well as at the economic arrangements for creating and maintaining the efficiency of the compensating mechanism.

Due to the sociological objectives, scientific approaches and activities necessarily have an influence on the relationship of tension between that member of society who wants to obtain something from the insurer and the insurer himself.

Between them an objective or an only seemingly neutral position of interest of the general public is building up. Other than in some fields of natural sciences, valuations enter the scientific problems from the very start.

If, instead of the generally used term of "practice", I speak about the application of the results of science and of the rules and experience as they present themselves in technique, it becomes evident that these are applications made on the basis of certain positions ; in insurance law on the basis of the position of the insured, the insurer, the judge or the supervisory office; in insurance medecine on the basis of the medical facts stated, i.e. diagnosis, therapy and rehabilitation based on the initial positions - subject to the situation of interests - of preventive medecine, including measures for promoting public health.

19 Cf. here only Mahr, Einführung in die Versicherungswirtschaft, 1951, pp. $76 \mathrm{ff}$.

20 In this respect now e.g. Noelle-Neumann, Die Schweigespirale, 1980, pp. 97 ff., $164 \mathrm{ff}$. 
In a state with a pluralistic social system and a free enterprise structure the rules and functions of insurance technique, as meant and applied in this paper, are also determined by the "casting" of the persons acting. The problem of economy and of the neutral functions aiming at justice and the social and economic overall interest consists in recognizing and representing what is "true and correct", however relative this may be, without it being possible to comment here on the dispute concerning valuation and critical realism.

\section{Significance of economic sciences and mathematics for technique and application}

This chapter begins with ideas and indications concerning the economic sciences of insurance which according to the nature of the matter are necessarily joined by mathematical aspects. As regards the relationship between science and practice the biggest steps were made in these fields in the past 30 years ${ }^{21}$. Among the examples that could be mentioned here we have to think of the scientific works for integrating insurance into the systems of the national economy ${ }^{22}$ - a very laborious undertaking that up to now has only been partially successful. Nevertheless it is worth noting that recognizing insurance as a "commodity" 23 and relating it to other services has had a direct influence on the overall conception of practice. Thought can be extended in the direction of integrating insurance into the difficult systems of economic structures 24 .

One chapter of research, that has also had a considerable effect on insurance practice, concernes the economic findings regarding monetary problems ${ }^{25}$. Since most insurance relationships have the character of permanent obligations, they last through time and in their economic balance of consideration and counter-consideration they thus collide with the curves of monetary development. The overall discussion on indexation joins in this context ${ }^{26}$.

If we consider that up to the twenties of this century insurance had for the most part been the scientific sphere of lawyers and that for various reasons economists entered this field step by step only, we are in a position to appreciate the works on

$21 \mathrm{Cf}$. the (unpublished) report by Jewell on the main subject 1 (Generalized models of the Insurance Business) at the 21st International Congress of Actuaries (Zurich and Lausanne) 1980.

22 In this respect Braeß, VW 1958, pp. $521 \mathrm{ff}$; Hippler, Wirtschaft und Statistik 1970, p. 331 ff. ; Andrae, ZVersWiss 1976, pp. 1 ff.; Farny, ZVersWiss 1979, pp. 31 ff. ; Seuss, ZVersWiss 1979, pp. 75 ff.

23 Farny, in Wirtschaft und Recht der Versicherung, Paul BraeB zum 66. Geburtstag, 1969, pp. 27 ff., 41.

24 Cf. e.g. Stöckbauer, Versicherung und Wirtschaftsordnung, 1978.

25 Cf. e.g. Loubergé and others, in Etudes et Dossiers No. 33 of the Geneva Association; Galitz and Revell, ibid., no. 40 ; Emil Frey, ZVersWiss 1972, pp. 315 ff.

26 Reimer Schmidt and others, ZVersWiss 1970, pp. 63 ff. ; idem. in Köth/Reichert/ Facilides, Inflationsbewältigung im Zivil- und Arbeitsrecht, 1976, pp. 123 ff. 
the theory of the insurance market ${ }^{27}$ even more. This is particularly true of the micro-economic statements and conclusions.

Scientifically moving and of extreme significance for practice is the system of ideas concerning the use of the firmly defined mathematical terms and functions of the probability calculus in the risk theory field ${ }^{28}$, the distance between modern risk theory itself and the initial positions for a practical application being extraordinary large. Therefore, there are considerable difficulties of communication in this respect. Due to the fact that the "concrete" filling the way of looking at these problems from the traditional actuarial points of view of life insurance has been largely removed, it is becoming evident that the possibility of findings concerning the subject of insurance depends on the degree to which the mentioned sets of questions are being penetrated. Let us just think of the judgement on collectives that numerically are not sufficient (too small) to allow an equilibrium or the pathbreaking finding of Braess ${ }^{29}$ that inhomogenous risks, too, can be put together to collectives allowing an equilibrium.

Part of this context are also the numerous works on the various starting points of a business management theory for insurance companies, the starting points based on factors, functions ${ }^{30}$ or the decision theory ${ }^{31}$. We should point out the interesting connection between operation research methods and advanced actuarial theories in life insurance for producing long-term prognoses on the profit expectations of partial collectives ${ }^{32}$. Aspects of business management, tax and above all probability theory ${ }^{33}$ join in the works on the different methods of a possible supratemporal balancing of collectives, such as e.g. the rule applicable in Germany for the so-called equilization reserves ${ }^{34}$. Finally, part of this context concerns considerations on a business management/mathematical level on the problem of solvency and the EC solvency models ${ }^{35}$.

As a matter of course, the struggle for a decision theory based on managerial economics finds its continuation in the field of insurance, without any appreciable reactions in practical conduct having up to now become evident. As a whole, however, the "outside effects" 36 of managerial economics become particularly evident in the field of personal lines insurance.

27 Farny, Die Versicherungsmärkte, 1961.

28 Karten, in Festschrift für Müller-Lutz, 1972, pp. 147 ff. ; idem., ZVersWiss 1972, pp. $279 \mathrm{ff}$.

29 Braeß, Versicherungs und Risiko, in Die Wirtschaftswissenschaften, Series B No. 25, 1960 ; idem., Zum Problem "gleichartiger Bedrohung' i.S. der Versicherungsdefinition von Alfred Manes, ZVersWiss 1963, p. 313.

30 Farny, Festschrift Braeß, ibid., pp. 27 ff. ; cf. also Eisen, ZVersWiss 1971, pp. 407 ff.

31 Karten, HWB, 4th edition, vol. 3 1976, columns $4246 \mathrm{ff}$.

32 I thank Dipl.-Math. Dr. Weippert for having drawn my attention to this fact; Gessner, VW 1980, pp. 479 ff.

33 G. Schmidt, Der optimale Versicherungsbestand, 1963.

34 In this respect Karten in Geneva Papers on Risk and Insurance no. 17, pp. 54 ff.; idem., in Festschrift für Gerhardt, 1975, pp. 379 ff.; cf. Braeß, ZVersWiss 1964, pp. 1 ff.

35 In this respect here D. Hesberg, ZVersWiss 1976, pp. 379 ff ; cf. BraeB, ZVersWiss 1964, pp. 1 ff.

36 Referring to his specific field of science, Bierfelder, on the environmental relations of managerial economics, Z.f. Betriebswirtschaft, 1980, p. 207. 
In contrast to this, the regulations for accounting ${ }^{37}$ capital investment, administration, corporate organization ${ }^{38}$, as well as the discussion concerning the separation of insurance classes ${ }^{39}$, are rather part of the technique in the sense indicated above, but they also provoke in part scientific disputes, such as the question of categorizing reinsurance commissions according to aspects of business management. The dispute on whether risk management considerations have to be assigned to science or to technique is not to be treated here ${ }^{40}$.

\section{The significance of jurisprudence for technique and application}

If one looks at the significance the research of jurisprudence has on insurance there is the statement in the foreground that - apart from the jurisdiction by the German Federal Supreme Court (Bundesgerichtshof) - the intellectual impulses generated in the field of insurance contract law in the past thirty years are completely lagging behind those shown in general economic law (e.g. in the law on economy administration, in corporate law and in trust law) incorporating the law on insurance supervision and cartel law. This surely is also attributable to the fact that the practical need for a further clarification of the facts of the law of contract - a clarification that has involved the work of three generations - is lagging behind the latter fields. For the law of contract certain new features were emphasized by the consumerism movement ${ }^{41}$. The EC harmonization of the insurance contract law that is under preparation does not have scientific bases 42 .

In the beginning one should point out the general significance the interpretational doctrine ${ }^{43}$ has with respect to laws, general insurance conditions as well as to declarations of intention. What has been said before on the significance of language for science also has its full effect here.

Hans Dölle ${ }^{44}$ showed those fields where in his opinion the human mind has brought about especially creative legal accomplishments. Of course we have to mention

37 See Welzel VW 1968, pp. 943 ff.

38 Cf. e.g. Müller-Lutz, Einführung in die Versicherungsbetriebslehre, 1980; Reimer Schmidt, ArchCivPrax, vol. 166, pp. 1 ff.

39 Rohde, Liebenau, Spartentrennung als Ordnungsprinzip, ZVersWiss 1973, pp. 509 ff.; Reimer Schmidt, ZVersWiss 1964, pp. 265 ff. ; H. Möller, ZVersWiss 1979, pp. 147 ff.

40 Cf. G. Schmidt, ZVersWiss 1978, pp. 85 ff.

41 Reimer Schmidt, Das Versicherungsrecht in der Wirtschaftsordnung, in "Vielseitige Rückversicherung", Aachen 1978, pp. 31 ff. ; cf. also L. Raiser, ZVersWiss 1978, pp. 375 ff. ; W. Vogel, Staatliche Beeinflussung von Konsumentenversicherungsverträgen, 1980.

42 Cf. Vorschlag fur eine Richtlinie des Rates zur Koordinierung der Rechts- und Verwaltungsvorschriften über Versicherungsverträge Abl.d.EG, no. C 190 of July 28,1979 , p. 2 ; Meyer-Kahlen, Angleichung des Versicherungsvertragsrechts im Gemeinsamen Markt, 1980.

43 In this respect e.g. Soergel/Siebert/Reimer Schmidt, 10th edition, vol. 1, 1967, Introductory Remarks, pp. 103 ff. ; Lorenz, Methodenlehre der Rechtswissenschaften, 4th edition 1979, pp. $298 \mathrm{ff}$.

44 Dölle, Juristische Entdeckungen, Verh. 42 Dt. Juristentag, 1957, vol. 2. 
Staub's doctrine of positive breach of claim, von Ihering's in culpa in contrahendo, the doctrine of reversionary rights, the contract with protective effect for third parties, the new doctrine of enrichment, etc. These discoveries in the field of general contractual law indirectly had considerable effects on the practice of insurance, such as e.g. the various stages of precising the facts of art. 823. Also under the influence of the extraordinary econnomic and social effects of claims compensation after car accidents the development is now moving more "towards insurance". Just think of the efforts for standardizing the measure of negligence, the continuous extension of the circle of obligatory insurance $\mathbf{4 5}$ and - here we come to works directly related to insurance the studies taken up again and again as regards the relationship between legal and contractual liability and liability insurance ${ }^{46}$. The scientific discussion is reaching into the argument over day to day politics.

In the law on insurance supervision the scientific ideas concerning the object and the justification of state supervision ${ }^{47}$, the delimitation of the field of companies subject to supervision and finally the "instruments" of current supervision have been in direct touch with practice, if one deliberately disregards in this paper the entire complex of the discussion for gaining acceptance of the Common Market principles of legal politics for the insurance field. Individual complexes, however, have to be mentioned, such as the works concerning the so-called principle of equal treatment of policy holders, declarations under the business plan and portfolio transfers.

The share of jurisdiction in the development of the Civil law bordering on insurance law and the law on insurance contracts itself seems to be, by far, larger to the author than the impulses science has set off in these fields. Just to mention two examples, this development starts with the views of the Supreme Court of the German Reich (Reichsgericht) concerning concealed obligations $\mathbf{4 8}$ (it was then carried on by Möller, other scientists and the Federal Supreme Court - BGH) and for product liability it is reaching from the famous fowl-pest case ${ }^{49}$ to the developments of the day.

It is of general significance, however, that as early as in the insurance contract law (VVG) of 1908 the obligations of the policy holder were diminished in his legal position as far as the treatment of the risk was concerned. Just think of the obligations and the different systems of diminished legal consequences that are also interesting

45 References concerning the ideas above are deliberately dispensed with.

46 The dispute has been going on for a generation, starting with Hans Möller, Die Uberwindung der Haftpflichtversicherung (JW 1934, pp. $1076 \mathrm{ff}$.) over the essential ideas of Karl Sieg (ZHR vol. 113, pp. 95 ff., idem., Ausstrahlungen der Haftpflichtversicherung, 1952) to Eicke von Hippel (Schadensausgleich bei Verkehrsunfällen, 1968) and Deutsch (Juristische Blätter 1980, pp. 298 ff.) ; cf. also the publications on the Karlsruhe Forum. The discussion has by far passed German borders, only to mention Keeton, O'Connell, Basis Protection for the traffic victim, 1965, as well as Tunc, La sécurité routière, 1966; (cf. also Prölss-Martin, VVG, 22nd ed. 1980 , art. 149 note 5,8 with numerous references) without it having been possible up to now to find a model of claims distribution replacing liability insurance and meeting all requirements.

47 Cf. Prölss/Schmidt/Sasse, VAG, 8th ed. 1978, pp. $10 \mathrm{ff}$. ; Michaels, Staatsaufsicht über Versicherungsunternehmen und Kreditinstitute, Vergleichende juristische Uberlegungen, 1967, pp. 1 ff., 43 ff.

48 RG JW 1922, column 100.

49 BGHZ 51, p. 91. 
to look at on the basis of comparative law and, in the case of risk restrictions, the exclusion of legal consequences if the event insured against was caused by merely slight negligence. In addition, the improvement of the legal position of the policy holder if he breaks an obligation or if he brings about the event insured against, was continued by science and jurisdiction by the creation of the representative concept which, by the way, in its result compares with Prölss' doctrine of the restrictively analogous application of art. 278 of the German Civil Code (BGB).

Part of the same global context of ideas is also the step by step improvement - essentially enhanced by science - of the legal position of the injured third party, above all in motor liability insurance. In this context, by the way, it has to be noted as a negative fact that unfortunately there is an inclination towards uncritically transferring the thinking models and results of the field of obligatory motor liability insurance to other insurance fields.

Thinking of the ideas and looking at the impulses of science for the practice of insurance does not lead to particularly flattering results for the science of insurance over the past thirty years. Only in a few cases ${ }^{50}$ legislation striving for reforms was able to base itself on significant and furthering results of science as material for reform projects. To a certain extent this criticism is also applicable to economic science and sociology.

\section{A short remark on the significance of sociology and psychology}

A study of the substantial positions of the significance of insurance science for practice would have to be supplemented by an examination of the sociological and psychological starting points. In this lecture, however, it is not possible to study the "relationship between economic science and jurisprudence, sociology and statistics" 51 more closely or to do so with a view to insurance practice. Continuing the ideas presented by Emil Frey in the festschrift for Braeß ${ }^{52}$ this concerns the independance of science, but also its willingness to think of the effects its results have on practice and of the possibility of practice to register the basic scientific positions and to utilize the results of science for practice ; i.e. above all this concerns a mutual open-mindedness, such as in the field of technical sciences this is a matter of course for science as well as for those working in technique and application. This open-mindedness is all the more important since science is continuously bound to create inconveniences for practice, whereas a purpose-free research, on the other hand, may easily lead to an isolated position of science in a socio-psychological sense.

50 Schmidt-Salzer, Allgemeine Geschäftsbedingungen, 2nd ed. 1972 ; Eike von Hippel, Verbraucherschutz, 1974.

51 Thus reads the title of an anthology edicted by $L$. Raiser a. o. on the working negotiations of the Verein für Socialpolitik, 1964, cf. in particular Coing, p. 2 and Mestmäcker, p. 103; Raisch and K. Schmidt, Rechtswissenschaft und Nachbarwissenschaften 1, 2nd edition 1976 , pp. $143 \mathrm{ff}$.

52 Emil Frey in Festsch. Braeß, ibid. pp. 73 ff. 


\section{The significance of insurance practice for science}

This already poses the reverse question for the significance of practice for the science of our sector. While science might give an answer to the question of practice "what can we do?" or "what should we do?" practice offers an initial basis for its chains of thought as well as a test field to science in those fields where the latter is concerned with the questions of "feasibility" as such, the translation into the social level. The question of what extent basic research (" pure science without relation to practice") is possible in those partial fields of insurance science has an orientation towards social science leading into a basic socio-philosophical dispute. The question cannot be answered here. But seen from the various individual partial sciences there necessarily and as a matter of course is the decision of special problems from the higher level - figuratively speaking - of the parent science, such as the problems of insurance contract law being decided on the basis of general civil law or on the level of general administrative law; but this is a technical scientific question long solved.

Also in the future the relationship between science and practice in the field of insurance remains fascinating and mutating. There will always be a field of tension between institutionalized creative thinking and organized acting that will reveal surprises for both sides. The benefit for the general public, which is the important thing, depends on the aspiration for truth, on the power of ideas and their closeness to reality, on the one hand, and on the willingness to stimulate as well as to assimilate them and try to translate them into practice, on the other hand. However, in the future, neither "seismographically" registering the "pertinent" scientific results nor listening carefully to the zeitgeist (also) finding its expression in the special branches of science will replace personal experience and intuition for the practician. One will discover more and more, that the bases represented by scientific findings, assured techniques and critical experience are a secure starting point for advancing, if only to find out himself at what point uncertainty starts.

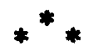

\section{Wissenschaft und Praxis der Versicherung * - Zusammenfassung}

In dem am 10.11.1980 vor dem Verein zur Förderung der Versicherungswissenschaft in München e.V. gehaltenen Vortrag (ZVersWiss 1980, S. $515 \mathrm{ff}$.) geht der Gedankengang des Verfassers aus von einigen Úberlegungen zum Wissenschaftsbegriff,

53 In this respect e.g. Only Albert, Konstruktion und Kritik, 1972, pp. 41 ff.

* Von Reimer Schmidt, Vorsitzender des Aufsichtsrats der Aachener und Münchener Beteiligungs-Aktiengesellschaft und der Aachener und Münchener Versicherung Aktiengesellschaft, Aachen. 
behandelt die einzelnen Versicherungswissenschaften und befaßt sich sodann eingehender mit ihren Einflüssen auf die Anwendung (Praxis) und schließlich notwendig recht kurz mit der Bedeutung der Versicherungspraxis für die Wissenschaften.

Zunächst begründet der Verfasser die Notwendigkeit, statt der Polarität zwischen Wissenschaft und Praxis eine dreistufige Gliederung, nämlich eine solche in Wissenschaft, Technik und Anwendung, hier bezogen auf die Versicherung, vorzuziehen. Im Gegensatz zu anderen Wissenschaftsbereichen zeigt sich in den Versicherungswissenschaften trotz der Internationalität der Praxis noch immer, daß diese nur beschränkt auf internationalen Plafonds angesiedelt sind, auch wird hier die Forschung mehr von Einzelforschern betrieben als in Gruppenforschung. Zudem ist in den letzten Jahren die Bedeutung von "Spezialsprachen" zur Präzisierung wissenschaftlicher Denkvorgänge und ihrer Utbermittlung in den einzelnen Fachrichtungen und damit auch in der Versicherungswirtschaft erkennbarer geworden.

Der Verfasser führt sodann aus, daß die Versicherungswissenschaft keine einheitliche sondern eine Sammelwissenschaft ist, wobei die Wissenschaft von ganz unterschiedlichen Ausgangspositionen der Einzelwissenschaften, z.B. der Mathematik, den ökonomischen Wissenschaften, der Rechtswissenschaft und der Medizin herangeht. Dabei ist es schwierig, übergeordnete Beurteilungsgesichtspunkte zu finden. Jedoch kann festgestellt werden, daß die Natur der Sache Versicherung, abgesehen von ihrer nicht einfachen volkswirtschaftlichen Einordnung, wesentliche mathematische und bedeutende mikroökonomische Akzente aufweist und daß Nutzen und Schaden der Anwendung vorwiegend unter gesellschafts-wissenschaftlichen Gesichtspunkten i.w.S. beurteilt werden. Betrachtet man die Anwendungsgebiete wissenschaftlichen Denkens auf dem Gebiet der Versicherung, so sind diese durch den Gesichtspunkt der Bedarfsdeckung und durch die besonderen, versicherungstypischen Methoden der Aufbringung der Mittel für die Bedarfsdeckung gekennzeichnet, bezüglich der Anwendung der Technik zeigt sich, daß es sich um Anwendungen aus bestimmten Positionen heraus handelt; bei dem Versicherungsrecht aus der Position des Versicherungsnehmers, des Versicherers usw., bei der Versicherungsmedizin aus der Position der medizinischen Sachverhaltsfeststellung usw. In einem Staat mit einer pluralistischen Gesellschaftsordnung und einer marktwirtschaftlichen Wirtschaftsverfassung sind die Regeln der Versicherungstechnik in der hier verwendeten Bedeutung und Anwendung von der "Rollenverteilung" der handelnden Personen mitbestimmt. Das Problem der Wissenschaft und der neutralen, auf die Gerechtigkeit und das gesellschaftliche und wirtschaftliche Gesamtinteresse bezogenen Funktionen besteht in dem Erkennen und Vertreten des, wie relativ auch immer, "Wahren und Richtigen".

Zur Bedeutung der Wirtschaftswissenschaften und der Mathematik für Technik und Anwendung ist zunächst zu betonen, daß die Beziehungen zwischen den Wirtschaftswissenschaften und Anwendung in der Versicherungswirtschaft in den letzten 30 Jahren die größten Schritte getan haben; erhebliche Auswirkungen auf die Praxis der Versicherung besitzen auch die ökonomischen Erkenntnisse zu Währungsproblemen. Wissenschaftlich bewegend und praktisch außerordentlich bedeutsam ist auch das Gedankenwerk um den Einsatz der fest definierten mathematischen Begriffe und Funktionen der Wahrscheinlichkeitsrechnung im Bereich der Risikotheorie, wobei der Abstand zwischen der modernen Risikotheorie selbst und den Ausgangspositionen für eine praktische Anwendung außerordentlich groß ist. 
Betrachtet man die Bedeutung der rechtswissenschaftlichen Forschung für die Versicherung, so steht im Vordergrund die Feststellung, daß - sieht man von der Rechtsprechung des Bundesgerichtshofs ab - in den letzten Jahrzehnten die geistigen Impulse hinter denen zurückbleiben, die vom allgemeinen Wirtschaftsrecht (z.B. im Wirtschaftsverwaltungs-, des Unternehmens- und Konzernrechts) unter Einbeziehung des Versicherungsaufsichts- und -kartellrechts ausgegangen sind. Hier darf ein Hinweis auf die allgemeine Bedeutung der Auslegungslehre, der auf Gesetze, auf Allgemeine Versicherungsbedingungen und auch der auf Willenserklärung bezogenen, für die Versicherung nicht fehlen; auch haben allgemein-schuldrechtliche Erfindungen, wie z.B. die Lehre von der positiven Forderungsverletzung, der culpa in contrahendo, die Lehre vom Anwartschaftsrecht, der Vertrag mit Schutzwirkung für Dritte, die neue Bereicherungslehre usw. mittelbar erhebliche Auswirkungen auf die Versicherungspraxis gehabt, z.B. auch die verschiedenen Schichten der Präzisierung der Tatbestände des $\S 823$ BGB. Die Entwicklung bewegt sich - auch unter dem Einfluß der außergewöhnlichen wirtschaftlichen und sozialen Auswirkungen des Schadenausgleichs nach Autounfällen - nunmehr "zur Versicherung" hin. Man denke an die Bemühungen um die Typisierung des Fahrlässigkeitsmaßstabes, die ständige Ausdehnung der Versicherungspflichten und die Untersuchungen über das Verhältnis von materieller Haftung und Haftpflichtversicherung. Im Versicherungsaufsichtsrecht bringen die wissenschaftlichen Gedanken über Zweck und Rechtfertigung der Staatsaufsicht, über Abgrenzung des Bereichs der unter Staatsaufsicht gestellten Unternehmen und schließlich über "Instrumente" der laufenden Aufsicht die unmittelbare Berührung zur Praxis.

Die Frage der Bedeutung von Soziologie und Psychologie wird vom Verfasser nur aufgeworfen. Dabei geht es um die Unabhängigkeit der Wissenschaft, aber auch um ihre Bereitschaft, an die Auswirkungen ihrer Ergebnisse auf die Praxis zu denken und an die Möglichkeit der Praxis, wissenschaftliche Ausgangspositionen zu erfassen und die Ergebnisse der Wissenschaft für die Praxis auszuwerten; vor allem also um die wechselseitige Aufgeschlossenheit. Diese ist um so wichtiger, als die Wissenschaft der Praxis notwendig laufend Unbequemlichkeiten bereitet, während die zweckfreie Forschung andererseits diese Forschung leicht zu einer sozialpsychologischen Alleinstellung bringt.

Zum Abschluß seiner Ausführungen befaßt sich der Verfasser mit der Bedeutung der Versicherungspraxis für die Wissenschaft. Die Praxis bietet der Wissenschaft dort, wo es dieser überhaupt um "Vollziehbarkeit", um eine Umsetzung in die gesellschaftliche Ebene geht, sowohl die Ausgangsbasis für ihre Gedankenketten wie auch ihr Erprobungsfeld. Die Wissenschafts-Praxis-Relation im Bereich der Versicherung wird auch zukünftig faszinierend und mutierend wirken. Das institutionalisierte kreative Denken und das organisierte Handeln werden stets in einem Spannungsfeld zueinander stehen, in welchem es für beide Seiten Überaschungen geben wird. Der Nutzen der Allgemeinheit, auf den es hier ankommt, hängt einerseits von dem Streben nach Wahrheit, von der Kraft der Gedanken und ihrer Wirklichkeitsnähe und andererseits von der Bereitschaft ab, sie sowohl anzuregen als auch aufzunehmen und ihre Umsetzung zu versuchen. Dem Praktiker wird auch zukünftig kein "seismographisches" Registrieren der " einschlägigen" Ergebnisse der Wissenschaft, kein noch so sorgfältiges Horchen auf den in den Fachwissenschaften (auch) zum Ausdruck 
kommenden Zeitgeist die persönliche Erfahrung und Intuition ersetzen. Der Praktiker wird aber in zunehmendem Maße feststellen, daß die Sockel wissenschaftlicher Erkenntnisse und gesicherter Techniken für weiterführende oder auch kritische Erfahrungen eine gesicherte Ausgangsbasis sind, wenn auch nur, um selbst festzustellen, in welchem Punkt die Unsicherheit beginnt. 